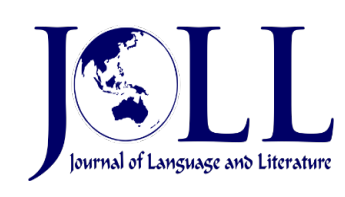

Vol. 21 No. 1, April 2021, pp. 160 - 171

DOI: 10.24071/joll.v21i1.3006

Available at https://e-journal.usd.ac.id/index.php/JOLL/index

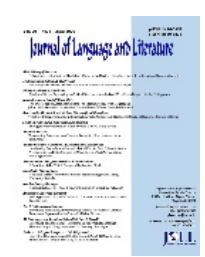

This work is licensed under a Creative Commons Attribution-ShareAlike 4.0 International License.

\title{
The "Super" Traditional Dancer: Her Shared Destiny with Common Superhero
}

\author{
Widya Nirmalawati1,2, Andrik Purwasito², Warto², Sri Kusumo Habsari ${ }^{2}$ \\ widya.nirmalawati@gmail.com, andrikpurwasito@staff.uns, warto_file@yahoo.com, \\ skhabsari@staff.uns.ac.id. \\ 1Faculty of Letters, Universitas Muhammadiyah Purwokerto, INDONESIA \\ ${ }^{2}$ Cultural Studies of Post-Graduate Programs, Universitas Sebelas Maret, INDONESIA
}

\begin{abstract}
Being a ronggeng dancer constitutes a turning point in a life to be at an upper level of humanity. It is similar to Superman who needs a special stone to be in his superiority, and other heroes with their specialties. A ronggeng, a Javanese traditional dancer, should be gifted with an indang spirit believed to be the dancer maker. For Srintil case, in Ronggeng Dukuh Paruk novel, she is at a much higher level compared to the others. She is the last to live in the shift of the culture. This study aimed to reveal Srintil's superhero characteristics and what destroyed her heroism. It is a qualitative study using the heroism concept. The techniques of collecting the data were reading, note-taking, and documenting in the form of narration and dialogue taken from the novel in accordance with the research problem. The finding showed there are four criteria that made Srintil a superhero for Dukuh Paruk's people: how she obtained a superpower; her journey to be a ronggeng; her willingness to help others; and how she sacrifices her life. However, there were men of the super culture who destroyed Srintil heroism. The indang had also prevented her from realizing her dreams, including having a true lover and having a family. Furthermore, it only left her with miseries by ended up in prison and insanity.
\end{abstract}

Article information

Received:

26 December

2020

Revised:

8 February

2021

Accepted:

14 February

2021

Keywords: Ronggeng Dukuh Paruk; Ahmad Tohari; superhero; heroism

\section{Introduction}

In a novel, a hero or heroine is one of the important elements in narrating a story. The word "hero" in English is taken from the word hero or warrior in Greek (Goethals \& Allison, 2012), (Hafçı \& Aslitürk, 2017). Literally, it means guardian or defender. According to
Merriam-Webster, a hero is a person "who shows great courage, the principal male character in a literary or dramatic work, or the central figure in an event, period, or movement" (Mish, n.d.). Traditionally, heroes are those who bravely overcome an opponent through their mental or physical strength power (Shang, 2018). They seek a virtuous 
manner, and willingly acts to help people and not being afraid to risk themselves, without being motivated by reward (Zimbardi via (Kohen et al., 2017)), (Johannesson, 2015).

From the definition above, we can refer that superhero in a fictional character is someone who has a super power, devotes himself to protect humans, and fight against criminals. Superheroes are born from comics or cartoons, and are described as having abnormal powers, for example being able to fly, have extraordinary energy, and are always portrayed as characters who fight against criminals and crime. A similar description is as mentioned in the Merriam-Webster dictionary, that they have skills that are beyond human reason or logic in general (Mish, n.d.). Their strengths can be obtained from non-human sources, superhuman biology, or from technology, i.e. Superman who comes from outer space or marvel's hero Iron Man, who obtained his power from technology. A superhero was characterized by the possession of a special ability or supernatural ability through the miracles of scientific science: genetic mutation (The X-Men); irradiation explorations (The Incredible Hulk), which differentiate them from the previous mythical heroes like Hercules, Hermes or Heracles (Winterbach, 2006), (Russell, 2014), (Oki, 2018) .

In line with the current definition of a superhero, where he/she provides good moral examples, the shift in genre between the portrayal of mythical heroes such as Heracles, King Arthur, and Arjuna, where they are portrayed as selfish, vengeful, and also thirst for blood (DeScioli \& Kurzban, 2008). Meanwhile, modern superheroes face dilemma whether to save billions of people by killing ones, war heroes, are famous for their amount of kills. They further explain how a superhero experienced a dilemma: an innocent bystander has been injured by a criminal. Should the bystander be rescued by the superhero, but let the perpetrator get away? Or should nailing the suspect be the top priority? What does a superhero do if more lives are eventually saved by going after the villain but causing the bystander to die? (DeScioli \& Kurzban, 2008). As the final remarks, DeScioli and Kurzban stated that superheroes are not heroes of war; they are heroes of morality. It is no mistake that even to save the universe, Superman will not destroy Rokk, that Batman refuses to specifically kill but allows Ra's Al Ghul to die, that Spider-Man neglects his personal life to save the Green Goblin, that Daredevil restrains his revenge against Kingpin, or that Xavier turns to his friend Magneto to protect human strangers. These common moral themes shape the superhero's pulse.

Besides showing a good morality, a superhero should also undertake a particular path which no one else does. From the process, the individual will have a certain power superior from others. The fact is one's courage is represented by the journey: Journey $\rightarrow$ intention $\rightarrow$ action. The path explores one's goal creation and offers insight into the sort of hero to become (Shang, 2018). Gatotkaca (a Javanese superhero who can fly) should be thrown into a place called candradimuka, a fire mud crater. Spiderman suffered from a poisonous bite of an enhanced spider. Stark spent all his time and money to design an armor or Superman who seemed insusceptible, also engage with suffering himself (Tembo, 2020). In case the history of a superhero making is revealed, it is always about the struggling process to which other people would not endure.

With all their "super", many superheroes are also described as normal and natural humans who have weakness in and fail to manage as flawless superhero. A superhero has their own weakness; Superman is defenseless against irradiation of the planet's leftover from where he came from; or Batman could not kill his enemy even when the enemy was a maniac killer; or Wonder Woman has a lasso that can becomes her weapon but in the same time can be her weakness (Levin et al., 2019), (Koole et al., 2014). Batman shows changes from being likeness to mythology into with the present day morality and values of the society (Barbosa \& Passos, 2020). He, who had been depicted in several stories ceases to be the "interventionist god" and learns to accept the fragility and shortcomings of the human condition. Batman blurred the distinction between black and white since his conception in 1939 (Born, 2017). In Tim Burton and 
Christopher Nolan's Batman films, this bipolar paradigm is challenged. The conventional dichotomy of good and bad was deconstructed by reversing its polarity and stressing the fictionality of all of it. While they vary in style and process, in favour of a more ambivalent and sophisticated perspective, both filmmakers invite us to resolve the Manichaean belief.

Another feature of a superhero that is most of superheroes are orphans (DeScioli \& Kurzban, 2008), (Levin et al., 2019). Superman who landed alone on Jonathan and Martha Kent's farm, then adopted by them and renamed after their names, as Clark Kent. The same thing also happened to Spiderman who adopted by his uncle, Ben. The wealthy Bruce Wayne, also became an orphan since he was child as his parents shot down by an armed gunman in an alley. In sum, no superheroes are flawless. Having superpower means bearing consequences, responsibilities, and also painful hardships.

Heroes are not born but they are made (Kohen et al., 2017). Apart from the definition of what and how to become a hero in a fictional character, there is a definition of a hero in real life. Everyone can be a hero and act heroically to everyone who needs help. To act heroically, there are at least four criteria: they pictured circumstances in which help is needed and they have capacity to help; as heroes in fictional stories, "real hero" also possess empathy without any discrimination; they always help in any circumstances; the last one is they have capability to help. These definition leads to the heroism concept. Heroism represent the ideal of people converting civic virtue into the highest type of civic action, embracing either physical risk or social sacrifice (Franco et al., 2011). Heroism, in other aspects of life, is associated with substantial risk and personal sacrifice, including severe financial implications, loss of social status, potential long-term health issues and social ostracism (Glazer, 1999). Adding a qualities of a hero, Selian, et al. who discussed the heroism in Rudyard Kipling's The Jungle Book, employed gratitude as one of heroism acts, besides giving protection, and defending rights (Selian et al., 2017). Gratitude became a distinguished element from the previous concepts of heroism. They explained how Mowgli expressed gratitude toward the wolf family who have taken care of him. So, heroism which mostly deal with risk and personal sacrifice, it also deals with showing gratitude.

Different from the previous articles which described the heroism process, heroism act and the heroic qualities, Nata, et al (2020) and Marcus (2018) pointed out on the costume worn by the hero. Nata, et al (2020) pointed out in the costuming of Black Panther movie. Using Pierce's theory this study suggest that the Black Panther costume represents the black race's life through physical shape, color, and symbolism. The costume is a product of the movement for Afrofuturism, a movement aimed at advocating for the African community. The Black Panther outfit reflects a vibrant and competitive community in Africa. Black people are pictured as a noble, civilized, progressive, creative, artistic, and warriorspirited nation by the character of Black Panther. The picture is an effort to sensitize the public about equality and harmony between groups in terms of human rights (Nata et al., 2020). Meanwhile, Marcus (2018) focused on the debate of the Wonder Woman costume, instead of her story of being admirable heroine-her heroic qualities reduced by her costume. He revealed how the Wonder Woman's dress changed from time to time based on the perceptions and criticism against her costume. The changing of her costume created a new perspective on feminism as well as the new representations of which it was produced (Marcus, 2018).

Referring to the definitions above, of course, Srintil does not fully fulfill the "super" criteria. Srintil is a woman character in a Ronggeng Dukuh Paruk (which from now on will be referred to as RDP) novel written by Indonesian famous author, Ahmad Tohari. Srintil is a well-known ronggeng in Dukuh Paruk Village. Besides entertaining she is also a culturally legalized prostitute. However, for the people of Dukuh Paruk, a ronggeng is their heroine and dignity. Even in the story, it is told that a wife will be very proud if her husband can "buy" ronggeng's virginity in bukak klambu ritual (a ritual which ronggeng virginity is sold to the highest bidder). To the wife, by winning 
the price in bukak klambu ritual, shows that her husband is rich and full of dignity.

A hero perhaps the most popular of a fictional character but at the same time, a hero means sacrificing their own normal life and welfare for the health and greater good of others (Johannesson, 2015). Srintil showed heroism in her struggling process to be a superronggeng. She also sacrificed many things for it. However, she ended up with miseries by ended up in prison and insanity. This research analyzed Srintil's superhero characteristics and what finally destroyed her heroism.

\section{Methodology}

The method of this research is descriptive qualitative research which aims to describe the existing reality based on concepts, categories, and not based on numbers. Qualitative methods are used to analyse various humanities social science problems, such as democracy, race, gender, class, globalization, freedom, and societal problems in general (Ratna, 2016). This method is used because it allows researchers to collect information about a phenomenon in a comprehensive manner. In this case, the researcher will collect, classify, analyse the collected data in the form of narrative quotes and dialogue which describe Srintil's superhero characteristics and what finally destroyed her heroism. The data were taken from RDP's English version, The Dancer.

\section{Results and Discussion}

The main problem of the people of Dukuh Paruk is "inferiority" which is entrenched in the minds of the people because of their ignorance in all aspects, education, social life, prosperity. Dukuh Paruk is synonymous with the world of rascals and evil. The only "good reputation" this village has is a ronggeng, a genuine traditional dancer who is only passed down by the Secamenggala spirit through the indang to the descendants of Secamenggala. So, the birth of ronggeng in Srintil is a panacea for all the inferiority. The passion for life in the community rose and brightly lit. The birth of ronggeng created a multilayered effect, a positive domino effect for the pulse of Paruk's life.

Therefore, Srintil is so respected, loved, and adored by all of people in Dukuh Paruk village. She became an idol for them. The Paruk people are willing to make sacrifices just to make Srintil happy. Paruk women are willing to bathe Srintil, massage her so that Srinthil's body remains in shape after dancing. They are also willing to sacrifice their goats so that their husbands can have the opportunity to dance with Srinitil in the courtyard. Like a superhero, Srintil is adored by many people, including other villagers. They always miss the Ronggeng present to dance and entertain them.

With these features, it is fair to attach the superonggeng label to Srintil. She has superpower obtained through indang, a kind of spirit that enters the body of a woman who is chosen to become ronggeng. Her skill of dancing with all her moves cannot be done by anyone other than herself, as an extraordinary skill. Meanwhile, Srintil has also proven to be a figure capable of getting rid of the big enemies of her society, namely poverty and inferiority. Srintil has clearly sacrificed her own life, to serve others.

\section{Srintil Heroism: Obtaining Super Power}

Like most superheroes who obtained their power from non-human sources, superhuman biology, or from technology, Srintil obtained her power by the indang. With this indang, a girl can become a superronggeng, without which she is only an ordinary dancer. No matter how hard a girl learns to dance unless the indang spirit resides in her body, she will not be a true ronggeng. The indang nature is freely entering to any girl based on the will of Secamenggala spirit. Srintil is the chosen figure, after the last eleven years of ronggeng leaving Dukuh Paruk.

In the hamlet there was a powerful belief that a true ronggeng dancer was not the result of teaching. No matter how she was trained, a young woman could not become a ronggeng dancer without being possessed by the indang spirit. In the world of ronggeng, the Indang was revered as a kind of supernatural godmother. (p. 8) 
The fact that Srintil was possessed by indang spirit firstly known by her grandfather, Sakarya. He saw Srintil danced and sang gaily without anyone teaching her. Seeing Srintil danced and sang that way, as a kamitua (head of the village) who has a responsibility to preserving the culture, he was very delighted to know that it was his own granddaughter who will continue the existence of ronggeng in Dukuh Paruk village.

The last ronggeng dancer in Paruk Village had died when Srintil was a baby. Yet, Srintil was able to dance with skill and conviction.

Vague feelings of lust and desire, always engendered by true ronggeng dancers, were aroused in her young audience by Srintil while she danced. The sweep of her neck, the glance of her eyes, even the way she swayed her shoulders would have mesmerized any adult male that saw her. (p. 8)

Her ability and the way she danced made his grandfather believe that Srintil was possessed by indang ronggeng spirit. For Dukuh Paruk, a true ronggeng is not born from teaching, but because the indang spirit enters the body of a ronggeng candidate. Indang is a kind of glorified spirit in the world of ronggeng (Tohari, 2012). Indang is a source of superpower not only gives privileges to a ronggeng, it also becomes an inherent responsibility. As Uncle Ben's message to Peter, "With great power, comes great responsibility." As a ronggeng, Srintil has the responsibility to be ready to "serve" the community. Srintil also fulfilled this obligation wholeheartedly. So, Sakarya, Srintil's grandfather, immediately contacted the ronggeng shaman, Kartareja. This was done because of the law of the village, that a ronggeng candidate must be hand over to the ronggeng shaman as a foster daughter.

Thereafter, they decided that, on an auspicious day, Srintil would be presented by her grandfather to Kartareja. The custom in the village for handling a potential ronggeng dancer was for the family of the candidate to give her over to the dukun to become his adopted child. (p. 13)

Similar to many heroes or superheroes in comic, namely Superman who landed alone on Jonathan Kent's farm from his faraway planet; or Batman who became an orphan as his parents shot down by an armed gun; and Spiderman who was left at his uncle's house before their parents, Srintil herself is an orphan because of Tempeh Bongkrek (a mixture of soybeans and coconut) disaster which caused many of Dukuh Paruk's children lost their parents. It seems that it is a common practice in narrative stories for a hero or superhero must be an orphan. Not only for modern superhero but mythical heroes also experienced the same things. DeScioli and Kurzban (2008) stated:

Many superheroes are orphans (e.g., Superman, Spider-Man, Batman), many undergo a period of training with $a$ knowledgeable teacher (e.g., Superman, Batman), and many possess a trademark weapon (e.g., Wonder Woman's lasso, captain America's shield). But the same properties are common among war heroes. For example, Achilles was an orphan, he was trained by chiron the centaur, and he killed with a special spear.

Being an orphan and is a kind of a gateway for a superhero to obtain the extra-power. Since they are orphans they are granted with superpower to face the hardship of life. Obtaining a superpower from non-human sources is not enough to save "the world", many superheroes also possess a weapon. As it is stated above, that many heroes possess weapons. Zorro, Xena and Wonder Woman are known for their lasso. Captain America with his shield, Thor with his hammer and Srintil is with the keris (a distinctive, asymmetrical dagger from Indonesia (Indonesian Kris, n.d.). Among Indonesian, especially Javanese, keris is considered possess a magical power that makes someone having a "spiritual power".

"They said that the keris is called Kyai Jaran Guyang-Venerable Potion of Love-and that it is a village heirloom which disappeared long ago. It is a love charm, 
used as a talisman by ronggeng dancers in the past. They also said that it is because of my success that the keris came into my hands. With this keris, I'll become a famous ronggeng. At least, that's what Grandpa and Kartareja said." (p. 42-43)

Therefore, besides indang, Srintil is also equipped with keris just the same like Marvel's superhero or other mythical heroes who possess a special weapon as their benchmark. In short, to become hero or superhero, one must possess an extraordinary power which obtained from non-human entities as well as obtaining a special weapon that distinguish them from an ordinary person. With their "extra-power" and also "extra-ordinary" weapon, made them unbeatable when opposing to the criminals.

From the above descriptions, Srintil deserves to be called as a hero. The way she obtained the power and possessing a weapon to support her power are similar to those wellknown superheroes. As a ronggeng, her power is in the form of dancing ability that distinguishes Srintil from other girl. Her appearance as ronggeng has long been awaited by the people of Dukuh Paruk, because by having a ronggeng, their village has become dignified. Sakarya dan Kertareja were the two men who contributed to the appearance of ronggeng in Dukuh Paruk. Both, had interest to perpetuate the existing culture in Dukuh Paruk village as well as the economic commodity from whom they live their life.

\section{Srintil's Journey as a Ronggeng}

The fact that Srintil had super skill, and charm far beyond the average girl in her village, made her became a "savior" for her own society. She transformed from an innocent little girl into a ronggeng that all the Dukuh Paruk girls dream about. Being a ronggeng in Dukuh Paruk was an honor. As a hero who helps many people, Srintil rescues the rongggeng tradition which is almost extinct after nearly eleven years of being abandoned by the last ronggeng. She was the panacea for Dukuh Paruk. However, as what Spider-Man had experienced--underwent a painful journey of being bitten by the spider which gave him a superpower; or as Gatotkaca who must be thrown to a fire-mud crater; so was Srintil. Before ratified as a ronggeng, Srintil went through a process that most superheroes go through. In a process of becoming a "superronggeng" she had to take many stages. The first stage was she must dance in front of Secamenggala's tomb. She almost lost her life, when the spirit of Secamenggala possessed the shaman and he hugged Srintil very strongly.

Suddenly the cheering and clapping stopped. Horrified, the village watched as Kartareja embraced Srintil so powerfully that the young girl gasped for breath. Srintil groaned in pain, as if she felt her ribs beaking from the pressure of Karaterja's powerful arms. (p. 48)

Dancing in the front of Secamenggala's tomb was not enough to ratify a ronggeng. The next stage was the hardest moment for Srintil. She had to lose her virginity in the bukak klambu ritual. Bukak klambu or "opening the cover of the bed" is the name of a contest of which Srintil's virginity is sold to the highest bidder. This ritual according to the shaman is to inaugurate a ronggeng to be able to carry out her profession as a fully and legally ronggeng. Once the bukak klambu ceremony is done, Srintil can ask for payment when she performs. Apart from being a dancer, ronggeng is also a prostitute. In other words, she is a culturally legalized prostitute. It seems that for this second role, the bukak klambu ritual further demonstrates Kartareja's power over Srintil's body.

The last ritual was called bukak klambu: "opening of the mosquito net." My hackles rose when I learned what this requirement was about. Bukak klambu is a type of competition, open to all men. What they compete for is the virginity of the candidate wishing to become a ronggeng dancer. The man who can pay the amount of money determined by the dancer's trainer has the right to take his pleasure with this virgin. (p. 51)

Bukak klambu is eventually an open gate for the shaman to "exploit" and earning money from Srintil. As a new ronggeng, Srinitl did not 
have a lot of choices. Since Srintil had to pay in return for Kertareja's "kindness" who has been educating and caring for her to become ronggeng. This kind of relation between Kartareja and Srintil can be called as a patronclient relation. Kertareja as the ronggeng patron, who already "invest" his resources to support the new ronggeng, in return Srintil (the client) reciprocates the gift by providing general support and assistance including personal favors to the patron. In Srintil case, as a client she just follows what is ordered by Kertareja as her patron for it is only the man who has resources and knowledge how to be a ronggeng. He even broke the custom of selling ronggeng's virginity to only the highest bidder. In fact, he sold Srintil's virginity to Dower and Sulam for the sake of money. With his power, he was freely determined the "price" of Srintil virginity in bukak klambu ritual no matter what it takes. Even when Srintil felt that she was sick during the bukak klambu ritual.

\author{
"You mean I have to entertain Sulam, \\ too?" \\ "It's nothing to worry about, is it? You'll \\ be the only child in Paruk to have a gold \\ piece." \\ "But my belly hurts, Grandma. It really \\ hurts." \\ "I once experienced something like this. \\ My beautiful child, believe me. It's nothing \\ to worry about. Just think, a gold piece! \\ Rest now, as long as Sulam is still \\ snoring." (p. 79)
}

From the dialogue between Srintil and Kartareja's wife, Srintil was so powerless against the Shaman, Ki Kartareja and his wife Nyi Kertareja. She only followed what was ordered by the shaman, because those are the steps that she must go through to become a ronggeng which was required by the ronggeng shaman and legitimized by the culture. By passing the painful bukak klambu ritual, Srintil was officially legitimate as a real ronggeng who could ask payment whenever she performed which gave her wealth and fame.

\section{Srintil: Between Morality and Freedom}

"Either you kill someone or Earth will be destroyed! you have twenty-four hours to make your decision." Superman reflects, "What a ghastly choice! Throughout my career I always protected life. Killing someone is against everything I stand for! yet, if I don't, those vicious aliens will blast the Earth and kill billions of people!" \#Superman 171 (DeScioli \& Kurzban, 2008).

The quotation above, was a dialogue between Superman and the two aliens, Rokk and Sorban, who bet whether Superman could kill someone or not. Superman facing dilemma, whether to kill Rokk or saving billions of people. In the end, Superman freed Rokk since it was against his moral conscience, though he knew that Rokk deserved dead. As it is stated by DeScioli and Kurzban, Superman is a moral absolutist. He will not kill anyone even by killing ones he saves billions of people. This kind of dilemma also experienced by Batman when he fights against Ra's al Ghul and also Srintil as well. Though Srintil did not fight against the "real" villain since her opponent was the poverty of people in Dukuh Paruk but she herself facing a moral dilemma. Whether to quit being a ronggeng of which she exploited by, the shaman, Kartareja, or continue dancing to help the members of ronggeng group whose life depend on ronggeng performance. Her moral conscience was at stake as she knew Sakum's family and other members of ronggeng lived in poverty because Srintil stopped dancing in ronggeng performance.

\begin{abstract}
Yet that night, Srintil could detect something different in the sound of Sakum's playing. Behind the blending of the music with the night was an implied irony, the irony of a calung player who was without work because the ronggeng no longer wanted to perform. Srintil smiled bitterly as she thought about Sakum's fate. The blind musician was the mascot of the ronggeng troupe. And it was not only he who had lost income as a result of her refusal to perform. Three other musicians were similarly affected. (p. 158)
\end{abstract}

Srintil decision to stop being ronggeng had many consequences. Not only has Sakum lost his job but other members of the ronggeng. Srintil facing a dilemma. On one hand, Srintil 
wanted to live normal as other woman; having a man to marry; having kids and family to go back by leaving her status as Dukuh Paruk's ronggeng. On the other hand, Srintil was a ronggeng whose life belong to culture. Even though she could neglect the life of the members of ronggeng's group for the sake of her happiness but as a Superman, Srintil was a moral royalist. She could not neglect them. Srintil finally decided to dance again for the lives of the ronggeng members. Srintil willingness to help is as coined by Kohen and Langdon (2017) about criteria to be a hero or act heroically: have capacity to help; possess empathy; help in any circumstances and have capability to help. Srintil possessed those four criteria. Her empathy towards the members of ronggeng group whose life depend on the ronggeng performance, drove her to quit her dream to be free from all ronggeng's matters. Her moral conscience lit forward rather than her willingness to be freed from her services as a ronggeng for Dukuh Paruk.

\section{Srintil's Sacrifices}

Becoming a hero means turning into a different human, an upper level of humanity as well as morality. Many superheros are described as sacrificing their life, and even career to help others (DeScioli \& Kurzban, 2008). When we look at Peter Parker, the Spider-Man, or even Bruce Batman, they also experience the same thing; they must lose their own life. They fail to find happiness with a lover or wife where they can live happily. This also happened to Srintil. As a natural woman, Srintil fell in love with his childhood friends, Rasus. However, it was forbidden, since she was a ronggeng.

"Has it ever happened that a ronggeng fell madly in love with a man?" asked one woman sitting with her friend beneath a jackfruit tree, searching her head for lice. "As far as I know, there's never been stories like that," her friend answered. "What's more typical is the man being crazy about ronggeng. After all, she's made to attract men. She can't become attached to anyone. So, how could she fall in love?" (p. 119)
Everyone in Dukuh Paruk understand the rule of being a ronggeng. Her body and even her life is not hers anymore. It belongs to a ronggeng culture. Stay single and unmarried are the rules. Eventhough it sounds unfair but these regulations passed down over the generation.

"Of course, there's nothing inherently
wrong with the idea of Srintil marrying
Rasus," Kartareja said to Nyai Sakarya.
"Not if she weren't a ronggeng wearing the
name Paruk Village on her sash, that is." (p.
129).

The ronggeng's rule is none other than a regulation made by a patriarchal cultural that is detrimental to women, in this case ronggeng. By spreading the discourse that a ronggeng should not fall in love, not marry and have children, makes Ronggeng's body turn into a cultural body. Being a cultural body creates obedient body that is always under surveillance. Such as the panopticon principle proposed by Jeremy Bentham. This happened because there were many parties who had an interest in Srintil's body as ronggeng. Economic motives are one of the reasons for how the ronggeng body should behave.

I had a strong feeling that Srintil had begun
to be haunted by the realization that Nyai
Kartareja had massaged her in a way that
had somehow destroyed her ability to
reproduce. The dukun and his wife would
have believed that they had to do this
because the custom in Paruk dictates that a
ronggeng's career would be finished with
her first pregnancy. I believed that Srintil
had begun to regard her apparent
infertility as a frightening ghost that would
haunt her for the rest of her life. (p.93)

Srintil's body which becomes the body of culture (men super culture) is another form of the existence of a long-standing patriarchal ideology which she had to pay for the rest of her life. There were two males who became traitors to Srintil's heroism, namely Bakar and Bajus. Whether it is a coincidence or purposively, Ahmad Tohari, gave the name Bakar means fire, connect to the Dukuh Paruk "burnt" incidents. He is the culprit who made 
Dukuh Paruk "burnt". He was the one who changed ronggeng from pride to humiliation due to the political labels. Apart from being a pillar of cultural facts about the existence and life of the art of ronggeng or tayub, RDP novel was also a collective memory for the people who owned it regarding the political event of the year 1965. This incident was linked to the role of ronggeng art which was innocently led by irresponsible people to become a propaganda medium. It becomes a vehicle that is metaphorized as a group of marginalized people who are oppressed, marginalized, and even "victims" of the injustice of the rulers, who are blamed as an instrument of capitalism. Likewise, the ronggeng group under Kartareja's care. The kindness given to the ronggeng group made them indebted to Bakar, including Srintil, the ronggeng.

In Srintil's eyes, Bakar was a perfect father figure. He was friendly, and seemed to understand many things including her personal feelings. His fatherly role was not only apparent from the generous amount of money he always paid her, but also evidenced in his cool disinterest regarding erotically-oriented matters. Bakar presented Srintil and her troupe with the gift of a complete sound system, the first electronic equipment to enter Paruk village, and it became a source of great pride among its inhabitants (p. 249)

Without Srintil and her group knowing, Bakar used them as media to attract the masses to smooth out his propaganda. Thus, even though Dukuh Paruk was experiencing a famine, the ronggeng group often got on stage, not in places where people in the Dukuh Paruk had a celebration, but at meetings organized by Bakar. He was like "elders" of which his words obeyed, and was carried out by the people of Dukuh Paruk. The actions the people took were compensation for Baker's kindness. Even when he put up a board in front of Kartareja's house. Bakar has the power to force the group to set it. Nobody was suspicious, even though they did not know what was written on the board, except for Sakarya, Srintil's grandfather. However, Kartareja could not do much. Until then, riots often occurred in Dukuh Paruk when Srintil and his entourage were on stage. They do not want to get involved in all the riots. Knowing that his position was endanger, Bakar, pitted the people of Dukuh Paruk by destroying Ki Secamenggala's grave.

The kindness that Bakar gave to the ronggeng group as their patron made them unable to escape from Bakar's power. The discourse of reciprocation has tied the group up without a fight which led to the arrest of Srintil and Kartareja with the label of PKI (Indonesian Communist Party) members. Being in jail has turned Srintil into different human. It was really a nightmare for Srintil. Her experienced with the "ronggeng world" that put her in jail has changed Srintil's mind.

She gave up for being a ronggeng and want to live "normal" as the other woman, being a somahan woman. Later she met Bajus. Bajus, is not just any man nor is he a love adventure. During the five months that he met her, Bajus treated Srintil politely and kindly. Bajus was a hope, a person who will make her a somahan (a true housewife) woman, a status she wanted to carry. It has been a long time since Srintil dreamed of becoming a somahan, having a man to marry, and Bajus was the one. His kind and polite treatment made Srintil obey what Bajus asked including when Bajus asked Srintil to go and company him to meet his relation. Srintil felt that was the way to repay Bajus for his kind treatment to her.

What Srintil experienced was a form of unequal power relations. Her obedience was a form of sacrifice for what he received from Bajus. According to Srintil, it was only Bajus who will bring her to have a such decent titlesomahan woman. Arriving at the intended place, instead of having all her dream came true, Srintil shaken up. Bajus asked her to company Pak Blengur. Pak Blengur was a person of which Bajus got big projects. He used Srintil's love to him as a stepping stone to get a big project from Pak Blengur. Srintil, who already stopped of being a ronggeng including doing her services as a culturally legal prostitute, strickly refused Bajus request.

"Um, you've meet Mr. Blengur. Believe me, he's a nice man. I'm sure that if you asked him for anything, whatever the price, he 
would give it to you. He's going to stay the night here. Sleep with him, will you? Spend the night with him, Srin. "

Srintil stiffened in shock, her eyes wide. Her mouth opened and her chest heaved rapidly. Her hands trembled.

...

“No!!" (p. 426)

Srintil's refusal of Bajus' request showed that she had complete power over her body unlike she used to be, when she carrying the "ronggeng of Dukuh Paruk" status. An adultery, which she desperately wanted to leave after giving up as a ronggeng, was asked by a man who has been hoped as a gateway to pursue her dream as a somahan woman. Srintil's refusal made Bajus angry, imagining that he will lose his project if Srintil refused to serve Pak Blengur.

"As a Paruk villager, you should remember who you are. You were a PKI member, a communist sympathizer! If you don't do what I say, I'll have you returned to prison. Do you think I can't do it?" (p. 427).

The PKI label that ruined her whole life, and made her stay in prison, was clearly visible in her memory. Srintil, whom at the beginning put a big hope to live "normal" (being a wife to Bajus) rather than being a superronggeng leads her to a misery. Her big effort to leave her title as a ronggeng destroyed as soon as Bajus asked her to do adultery. The biggest lost was just when Bajus suddenly said that he will send her to a prison as PKI, a prison was the hell world for her. With only a few words in a few seconds, in fact, has made a human losing her mind. Bajus "kills" Srintil consciousness. Bajus was the man who transformed Srintil from human to just a living creature. Now, Srintil is just only a woman without soul. A human without a soul is just no other than an animal. Her soul has just been taken away by Bajus, a cowardly man that ruined Srintil life.

Bakar and Bajus, selfishly turned out Srintil heroism into shamefulness. Both destroyed Srintil's humanity and heroism and led her into insanity. Kartareja and Sakarya were the man of super culture who put Srintil to fame and glory but their greediness has made Srintil lost her heroism. She whom at first became the hero for Dukuh Paruk's people by helping them out of the poverty, in the end it left her with misery. Though Srintil has indang as her power, but it is under Secamenggala's spirit order, which controlled by the shaman. It is due to the rule of super culture that long lived in Dukuh Paruk which created by men of the high ruler, Sakarya and Kartareja, as the kamitua (elders) in Dukuh Paruk. Srintil, then, is a powerless hero against the man super culture.

\section{Conclusion}

Based on the analysis above, there were four criteria that made Srintil become a superhero for Dukuh Paruk's people: how she obtained a superpower; her journey to be a ronggeng; her willingness to help others; and how she sacrifices her life. However, there were men of the super culture who destroyed Srintil heroism. The first was Sakarya and Kartareja as the kamitua who have pinned that the indang spirit resides in Srintil. With the indang discourse they both confirmed Srintil as a ronggeng, to perpetuate the existing culture in Dukuh Paruk village. With their cultural knowledge, making Srintil obeyed their ordered as the noble duty of a ronggeng. The second was Bakar and Bajus, who originally came as heroes for Srintil. Both, did not want ronggeng services, to fulfill men's needs, which for the residents of Dukuh Paruk was legal. In fact, Bakar made Srintil have to accept the PKI label, for a mistake that she herself was not aware of. Meanwhile, Bajus, a man who uses Srintil's love for adultery, a world that she wanted to leave as hard as she could. From the narrative above, the indang who should have brought Srintil to become a hero for Dukuh Paruk had prevented her from realizing her dreams, including having a true lover and having a family. Furthermore, it only left her with miseries by ended up in prison and insanity. Her life path was just like any other superhero who failed to rule a normal life like everyone else, their true ideals. 


\section{References}

Barbosa, T., \& Passos, M. Y. (2020). Stepping out of Divinity: Tom King's "All-toohuman" Batman. Galactica Media. Galactica Media: Journal of Media Studies, 2(3), 89-118. https://doi.org/https://doi.org/10.4653 9/gmd.v2i3.117

Born, S. P. (2017). Shadows of the Bat: Constructions of Good and Evil in the Batman Movies of Tim Burton and Christopher Nolan. Journal for Religion, Film and Media, 3(1), 75-104. https://doi.org/10.25364/05.3:2017.1.5

DeScioli, P., \& Kurzban, R. (2008). Cracking the Superhero's Moral Code. In R. Rosenberg (Ed.), The Psychology of Superheroes (pp. 245-259). Texas: BenBella Books.

Franco, Z. E., Blau, K., \& Zimbardo, P. G. (2011). Article Menu Access Options Full Article Content List Abstract Our Prior Work on Heroes The Heroic Core in Overlapping Forms of Courage A Preliminary Attempt at an Operational Definition of Heroism The Relationship between 12 Heroic Types and Situations t. Review of General Psychology, 15(2), 99-113. https://doi.org/10.1037/a0022672

Glazer, M. P. (1999). On the Trail of Courageous Behavior. Sociological Inquiry, 69(2), 276-295. https://doi.org/https://doi.org/10.1111 /j.1475-682X.1999.tb00503.x

Goethals, G. R., \& Allison, S. T. (2012). Making Heroes: The Construction of Courage, Competence, and Virtue. Advances in Experimental Social Psychology, 46, 183235. https://doi.org/10.1016/B978-012-394281-4.00004-0

Hafçı, B., \& Aslitürk, G. E. (2017). Superheroes: Myths Of Modern Age? Idil, 6(30), 497510. https://doi.org/10.7816/idil-0630-02
Indonesian Kris. (n.d.). Retrieved October 3, 2020, from https://ich.unesco.org/en/RL/indonesia n-kris-00112

Johannesson, I. (2015). The Evolution of the Literary Hero: The Sociological Impacts on Hero Driven Literature. https://core.ac.uk/download/pdf/4356 0653.pdf

Kohen, A., Langdon, M., \& Riches, B. R. (2017). The Making of a Hero: Cultivating Empathy, Altruism, and Heroic Imagination. Journal of Humanistic Pychology, 59(1), 617-633. https://doi.org/10.1177/00221678177 08064

Koole, S. L., Fockenberg, D. A., Tops, M., \& Schneider, I. K. (2014). The Birth and Death of the Superhero Film. In J. Greenberg \& D. Sullivan (Eds.), Fade to bBack: Death in Cassic and Contemporary Cinema (pp. 1-23). Palgrave Macmillan. https://doi.org/10.1057/97811372768 96_9

Levin, J., Mclaren, P., \& Seale, S. (2019). Race, Identity and Superheroes. The International Journal of Critical Media Literacy, 1(1), 7-25. https://doi.org/10.1163/2590011000101001

Marcus, J. (2018). Wonder Woman's Costume as a Site for Feminist Debate. Imaginations, 9(2), 5-65. https://doi.org/10.17742/IMAGE.FCM.9. 2.6.

Mish, F. C. (Ed.). (n.d.). Merriam-Webster Collegiate Dictionary (11th ed.).

Nata, E. Y. R., Sumarwahyudi, \& Cendekia, D. A. (2020). Afrofuturism in Black Panther Superhero Costume as Culture Sustainability Media (Charles Sanders Pierce Semiotic Analysist). KnE Social Sciences, 4(12), 199-208. https://doi.org/https://doi.org/10.1850 2/kss.v4i12.7596 
Oki, E. (2018). The Polish Superheroes Have Arrived!: On the Popularity of Superhero Stories and Adaptations. European Journal of American Studies, 13-3. https://doi.org/10.4000/ejas.13678

Ratna, N. K. (2016). Metodologi Penelitian. Yogyakarta: Pustaka Pelajar.

Russell, C. (2014). Heroic Moments: A Study of Comic Book Superheroes in Real-World Society. Explorations Social Sciences, 121-131. https://uncw.edu/csurf/explorations/d ocuments/russell.pdf

Selian, H., Suhadi, J., \& Manugeren, M. (2017). Heroism In Rudyard Kipling's The Jungle Book. Language Literacy, 1(1), 51-72. https://doi.org/https://doi.org/10.3074 3/ll.v1i1.246

Shang, A. (2018). Who Are Heroes? An Analysis Of The Literary Hero And An Interpretation Of The Modern Hero. https://repositories.lib.utexas.edu/hand le/2152/65285

Tembo, K. (2020). Why Superman Will Not Save The World: Theorizing The Relationship Between Suffering And Dc Comics Superman. Galactica Media: Journal of Media Studies, 3, 119-137. https://doi.org/10.46539/gmd.v2i3.114

Tohari, A. (2012). The Dancer (R. T. Lysloff, Trans.). Jakarta: Lontar.

Winterbach, H. (2006). Heroes and Superheroes: From Myth to the American Comic Book. SAJAH, 21(1), 114-134. https://repository.up.ac.za/bitstream/h andle/2263/10798/Winterbach_Heroes (2006).pdf?seque 